\title{
Ectopic Agouti protein overexpression increases stimulated corticosterone production without effect on adenylate cyclase activity in mouse adrenal cells
}

\author{
Antonyna Y Shevchenko, Nadezhda M Bazhan, Elena N Makarova, Tatyana V Yakovleva and Nelli R Karkaeva
} Institute of Cytology and Genetics of the Russian Academy of Sciences, Pr. Lavrentjeva 10, Novosibirsk, 630090, Russia

(Correspondence should be addressed to A Y Shevchenko; Email: antonyna2000@yandex.ru)

\begin{abstract}
Objective: The antagonism of Agouti protein (AP) and Agouti-related protein on melanocortin receptors suggests an inhibitory role in the regulation of steroidogenesis. However, we have previously demonstrated that ectopic AP overexpression increased restraint-induced corticosterone release and adrenal reactivity to ACTH in mice. A high steroidogenic response to ACTH may be a consequence of a stimulatory AP action on the adenylate cyclase (AC) and/or intracellular steroidogenic enzymes. The aim of the present study was to estimate the effect of ectopic AP overexpression on the activity of $\mathrm{AC}$ and steroidogenic intracellular enzymes.

Methods: ACTH and forskolin were used for AC stimulation, and dibutyryl cAMP and progesterone were used for stimulation of intracellular steroidogenic enzymes in isolated adrenal cells in male C57Bl/6J mice of two Agouti genotypes: $A^{y / a}$ (ectopic AP overexpression) and $a / a$ (absence of AP in all tissues).

Results: ACTH and forskolin increased cAMP accumulation to the same extent in both $A^{y} / a$ and $a / a$ mouse adrenal cells $\left(P<0.001\right.$; ANOVA), but resulted in higher corticosterone production in $A^{y} / a$ mice $(P<0.001$ for ACTH and $P<0.01$ for forskolin; ANOVA). Dibutyryl cAMP- and progesterone-induced corticosterone production was higher in $A^{y} / a$ mice than in $a / a$ mice $(P<0.001$ for dibutyryl cAMP and $P<0.01$ for progesterone; ANOVA).

Conclusions: Ectopic AP overexpression increased stimulated corticosterone production and intracellular steroidogenic enzyme reactivity to cAMP without an effect on AC activity.
\end{abstract}

European Journal of Endocrinology 151 613-618

\section{Introduction}

The Agouti protein family includes Agouti protein (AP) and Agouti-related protein (AgRP). They have a striking similarity in structure and function (1), although their patterns of distribution in tissues are completely different. AP is a paracrine-signaling factor that is normally expressed only in the skin of rodents, regulating coat color (2). The human homolog of AP is expressed in a wide range of tissues, including adipose tissue, testis, ovary, heart, foreskin, kidney and liver (3). However, its physiological functions in human tissues remain unclear to date. AgRP is expressed primarily in the hypothalamus and adrenal cortex of humans and rodents, and at low levels in testis, lung and kidney of mice $(1,4,5)$. Central AgRP is involved in appetite regulation and energy balance, but little is known about AgRP function in adrenals and other peripheral tissues (1).

The most accepted mechanism for AP/AgRP action is a classical competitive antagonism of melanocortin receptors (MCRs) $(6,7)$. Some findings suggest that
AP not only inhibits the binding of agonists, but also alters the interaction of MCRs with intracellular effectors (8). Other studies have demonstrated that both $\mathrm{AP}$ and AgRP act as inverse agonists rather than classical competitive antagonists of MCRs (9). Thus, these authors $(8,9)$ suggest a more complex mechanism by which APs and the melanocortin peptides mediate a physiological response via the MCRs.

Melanocortin peptides (adrenocorticotropin (ACTH) and $\alpha$-melanocyte-stimulating hormone $(\alpha \mathrm{MSH}))$ are important regulators of the hypothalamic-pituitaryadrenal (HPA) axis. The role of APs in the regulation of HPA function, including steroidogenesis in the adrenal gland, is poorly understood, and findings are very conflicting $(10,11)$. Melanocortin receptors MC2-R (ACTH receptors), MC3-R, MC4-R and MC5-R have been found in the adrenal cortex $(4,5)$. The antagonism of APs on MCRs suggests its inhibitory role in the regulation of steroidogenesis. Human recombinant AP was demonstrated to be a potent inhibitor of MC2-R signaling in the adrenal cortical lineage (7). AgRP 
was shown to completely abolish $\alpha \mathrm{MSH}$-induced steroid secretion, mediating the inhibitory effect via MC3-R and MC4-R (5, 12). Nevertheless, basal and stress-activated corticosterone production was previously reported to be within normal limits in the Agouti yellow $\left(A^{y} / a\right)$ obese mice with overexpression of $\mathrm{AP}$ (10). Moreover, it has been shown that ectopic AP overexpression increases restraint-induced corticosterone release $(11,13)$, higher adrenal sensitivity to exogenous ACTH in vivo and an elevated response of the whole adrenal gland to ACTH stimulation in vitro (13).

Apparently the effect of ectopic AP overexpression on adrenal steroidogenesis is not limited only by the inhibition of ACTH receptors. It is possible that AP can modulate post-receptor signal transmission in adrenal cells. AP has been shown to increase the intracellular concentration of $\mathrm{Ca}^{2+}$ in myocytes and adipocytes $(14,15)$. It also increases gene expression in adipose tissue and the $\beta$-cells of the pancreas gland $(16,17)$. High steroidogenic response to ACTH in $A^{y} / a$ mice may be a consequence of the stimulatory action of $\mathrm{AP}$ on plasma membrane enzyme adenylate cyclase (AC) and/or intracellular steroidogenic enzymes.

The aim of this study was to estimate the effect of ectopic AP overexpression on the activity of AC and steroidogenic cAMP-dependent enzymes in adrenal cells. As a model of AP overexpression we used mice with the autosomal dominant mutation Agouti yellow $\left(A^{y} / a\right)(2)$. In this report, we have demonstrated that ectopic AP overexpression increased stimulated corticosterone production and intracellular steroidogenic enzyme reactivity to cAMP without an effect on AC activity.

\section{Materials and methods}

Materials were obtained from the following sources: corticosterone, ACTH(1-39), dibutyryl cAMP, forskolin, collagenase type 1A, 3-isobutyl-1-methylxanthine (IBMX), bovine serum albumin (BSA, fraction V) from Sigma Chemical Company, St Louis, MO, USA; $\left[{ }^{3} \mathrm{H}\right]$ corticosterone from Amersham Biosciences, Amersham, Bucks, UK; progesterone from Fluca, Buchs, Switzerland; cAMP RIA kits from Immunotech, Marseille, France.

\section{Animals}

The study was undertaken on 3-month-old male C57Bl/6J mice of two Agouti genotypes: $A^{y} / a$ with ectopic AP overexpression and $a / a$ with an absence of AP. Mice of $a / a$ and $A^{y / a}$ genotypes were siblings obtained from reciprocal crosses $A y / a \times a / a$ and $a / a \times A^{y / a}$. Animals were bred in the vivarium of the Institute of Cytology and Genetics (Siberian Division, Russian Academy of Science, Novosibirsk, Russia). They were housed in groups of five per cage under natural light conditions, at an ambient temperature of $21^{\circ} \mathrm{C}$ with free access to water and food. Animals were caged separately for 4 days before the experiments. $A^{y} / a$ mice weighed $27.1 \pm 1.1 \mathrm{~g}(n=15)$ and a/ $a$ mice weighed $25.7 \pm 0.4 \mathrm{~g}(n=13)$. Because of circadian rhythms, all experiments started at $0900 \mathrm{~h}$. All studies were carried out under the highest standards of humane animal care using the International European ethical standards (86/609-EEC) and Russian national instructions for the care and use of laboratory animals.

\section{Isolation and purification of adrenal cells}

Cells were prepared from adrenals by decapitation and collagenase digestion. Briefly, adrenals from five mice (of the same genotype) were cleaned of fat and cut into small pieces. Glands were removed and incubated in Krebs-Ringer bicarbonate buffer (KRB; pH 7.4; $1.5 \mathrm{ml} / 10$ glands) with $4 \% \mathrm{BSA}$ and $4 \%$ collagenase at $37^{\circ} \mathrm{C}$ in an atmosphere of $95 \% \mathrm{O}_{2}$ and $5 \% \mathrm{CO}_{2}$. After $60 \mathrm{~min}$, the suspension was dispersed by gentle homogenization (repeated pipetting), filtered through nylon gauze and centrifuged at $36 \mathrm{~g}$ for $10 \mathrm{~min}$ then at $96 \mathrm{~g}$ for $10 \mathrm{~min}$ at $4^{\circ} \mathrm{C}$. The suspension was washed three times with $2.5 \mathrm{ml}$ cold $\mathrm{KRB}$ with $0.5 \%$ BSA. After the final centrifugation, the cells were resuspended in $2.0 \mathrm{ml} \mathrm{KRB}$ with $0.5 \%$ BSA and counted with Trypan blue in a hemocytometer chamber. Cells were suspended in KRB with $0.5 \%$ BSA to a final concentration of $4 \times 10^{5}$ cells $/ \mathrm{ml}$ (to a total of $\sim 14 \times 10^{5}$ adrenal cells for each experiment) with a viability higher then $90 \%$, as determined using the Trypan blue method.

\section{Incubation of adrenal cells}

Aliquots $(0.2 \mathrm{ml})$ of adrenal cell suspension $\left(4 \times 10^{5}\right.$ cells $/ \mathrm{ml}$ ) were incubated in KRB with $0.5 \%$ BSA under an atmosphere of $95 \% \mathrm{O}_{2}$ and $5 \% \mathrm{CO}_{2}$ in the presence or absence of different doses of stimulators: ACTH $\left(10^{-13}, 10^{-12}, 10^{-11}, 10^{-10} \mathrm{M}\right)$ or forskolin $\left(10^{-6}\right.$, $\left.10^{-5}, 10^{-4} \mathrm{M}\right)$ or dibutyryl cAMP $\left(10^{-5}, 10^{-4}, 10^{-3}\right.$ M) or progesterone $(2 \mu \mathrm{g} / \mathrm{ml})$. After $2 \mathrm{~h}$ of incubation the suspension was centrifuged at $180 \boldsymbol{g}$ for $5 \mathrm{~min}$. The cell-free medium was decanted and stored at $-20{ }^{\circ} \mathrm{C}$ until assayed for corticosterone. Samples for the measurement of cAMP accumulation were collected in the same experiments immediately after the samples were decanted for the corticosterone assay. Three experiments were conducted, each in triplicate.

\section{Corticosterone assay}

Corticosterone was measured by competitive protein binding using serum from female mice with inner transcortin, and unlabeled and labeled corticosterone. Intra- and interassay coefficients of variation were less than 5 and $10 \%$ respectively. 


\section{cAMP assay}

In the cAMP experiments, 0.5M IBMX (phosphodiesterase inhibitor) was included in the medium (KRB). After samples were decanted for the corticosterone assay, the cells were resuspended in $0.1 \mathrm{ml}$ aliquots of KRB and cAMP production was terminated by the addition of $0.1 \mathrm{ml}$ perchloric acid (0.2 M). Cells were then disrupted by sonication for $4 \mathrm{~min}$. Samples were precipitated by centrifugation at $180 \boldsymbol{g}$ for $5 \mathrm{~min}$. The cell-free medium was decanted and stored at $-20{ }^{\circ} \mathrm{C}$ until cAMP assay. cAMP accumulations were determined by RIA according to the manufacturer's specification.

\section{Data analysis}

All data are expressed as the means \pm S.E.M. Statistical analysis was performed using two-way ANOVA with post hoc comparison by Newman-Keuls test. A difference between two means was considered to be statistically significant when $P<0.05$.

\section{Results}

There were no genotype differences in corticosterone production and cAMP accumulation in untreated adrenal cells in all experiments (Figs 1, 2, 3 and 4).

\section{Effects of ACTH and forskolin on cAMP accumulation in $A^{y} / a$ and a/a mice}

ACTH stimulation: ACTH at doses of $10^{-13}$ and $10^{-12} \mathrm{M}$ did not increase the cAMP level in either $A^{y} / a$ or $a / a$ mice. ACTH at doses of $10^{-11}$ and $10^{-10}$ $\mathrm{M}$ increased cAMP accumulation to the same extent in both genotypes $(P<0.001$; ANOVA) (Fig. 1A).

Forskolin stimulation: Forskolin at a dose of $10^{-6} \mathrm{M}$ had no effect on the cAMP level and higher doses $\left(10^{-5}\right.$ and $10^{-4} \mathrm{M}$ ) increased cAMP accumulation to the same extent in both genotypes $(P<0.001$; ANOVA $)$ (Fig. 1B).

\section{Effects of ACTH and forskolin on corticosterone production in $A^{y} / a$ and a/a mice}

ACTH stimulation: All ACTH doses markedly increased corticosterone production in both $A^{y / a}$ and $a / a$ mice $(P<0.001$; ANOVA) (Fig. 2A). The increase was greater in $A^{y} / a$ mice than that observed in $a / a$ mice $(P<0.001$; ANOVA). Corticosterone production achieved a plateau at the $10^{-12} \mathrm{M}$ ACTH dose in both $A^{y / a}$ and $a / a$ mice.

Forskolin stimulation: All forskolin doses markedly increased corticosterone production in both $A^{y} / a$ and a/ a mice $(P<0.001$; ANOVA) (Fig. 2B). The increase was greater in $A^{y} / a$ mice than in $a / a$ mice $(P<0.001$; ANOVA) with a maximal activation effect at $10^{-5} \mathrm{M}$, following a decline at $10^{-4} \mathrm{M}$ in both genotypes.
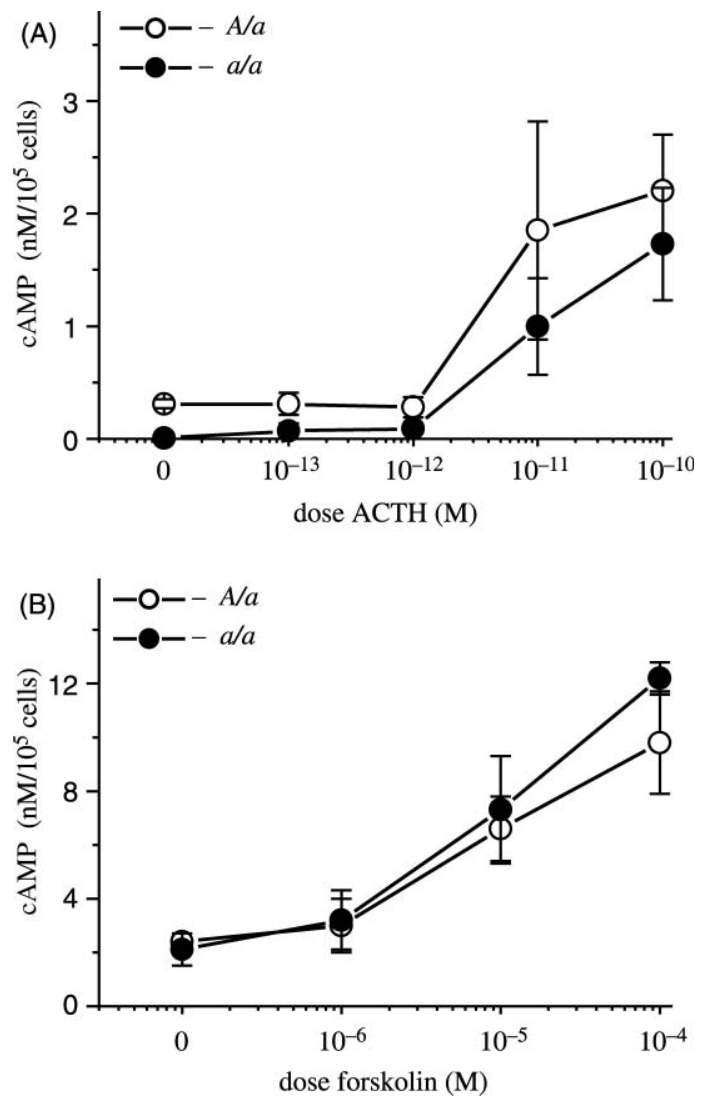

Figure 1 Effects of ACTH and forskolin on cAMP accumulation in $A^{y / a}$ and a/a mice. Adrenal cells were incubated for $2 \mathrm{~h}$ in the absence or presence of various doses of (A) ACTH or (B) forskolin. Each symbol represents the mean cAMP value from three experiments. In each experiment, corticosterone production was measured in three aliquots of cell suspension obtained from five mice. Data are the means \pm S.E.M.

\section{Effects of dibutyryl cAMP on corticosterone production in $A^{y} / a$ and a/a mice}

Dibutyryl cAMP at $10^{-4}$ and $10^{-3} \mathrm{M}$ progressively stimulated corticosterone production in both $A^{y / a}$ and $a / a$ mice $(P<0.001$; ANOVA) (Fig. 3). The effect of the Agouti genotype was significant $(P<0.01$; ANOVA): at a dose of $10^{-3} \mathrm{M}$ dibutyryl cAMP, $A^{y / a}$ mice showed a greater increase of corticosterone production compared with $a / a$ mice $(P<0.05$; Newman-Keuls test).

\section{Effects of progesterone on corticosterone production in $A^{y} / a$ and a/a mice}

Progesterone at $2 \mu \mathrm{g} / \mathrm{ml}$ stimulated corticosterone production in $A^{y} / a$ and $a / a$ mice $(P<0.001$; ANOVA) (Fig. 4). The effect of the Agouti genotype was significant $(P<0.01$; ANOVA $): A^{y} / a$ mice showed a greater increase of corticosterone production compared with a/a mice $(P<0.001$; Newman-Keuls test $)$. 

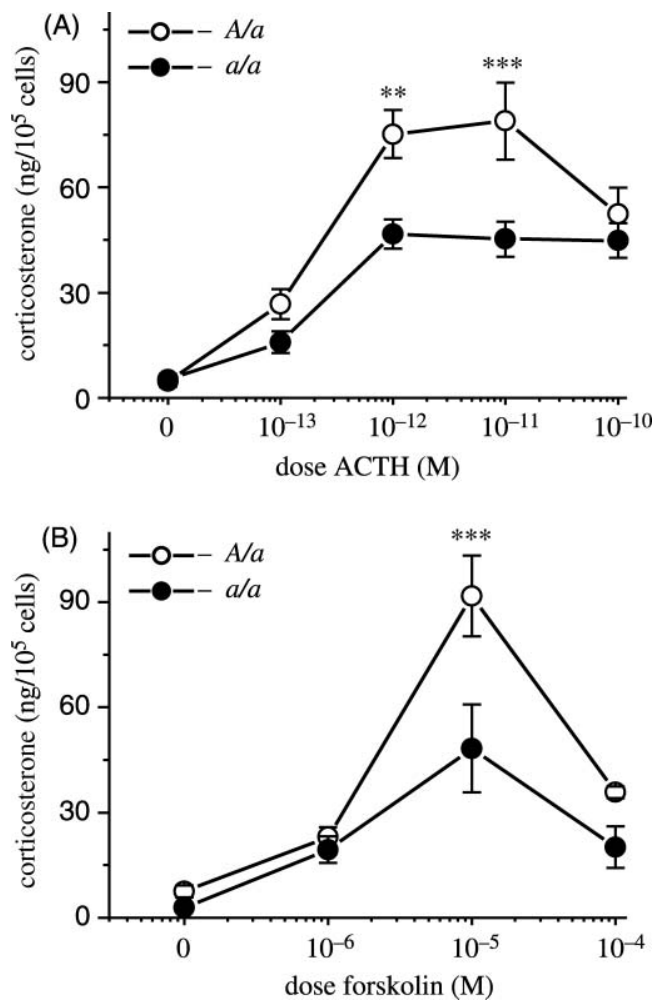

Figure 2 Effects of ACTH and forskolin on corticosterone production in $A^{y} / a$ and $a / a$ mice. Adrenal cells were incubated for $2 \mathrm{~h}$ in the absence or presence of various doses of (A) ACTH or (B) forskolin. Each symbol represents the mean corticosterone value from three experiments. In each experiment, corticosterone production was measured in three aliquots of cell suspension obtained from five mice. Data are the means \pm S.E.M. ${ }^{* *} P<0.01$ and ${ }^{* * *} P<0.001$ in $A^{y} /$ a mice vs a/a mice (ANOVA, post hoc comparison by Newman-Keuls test).

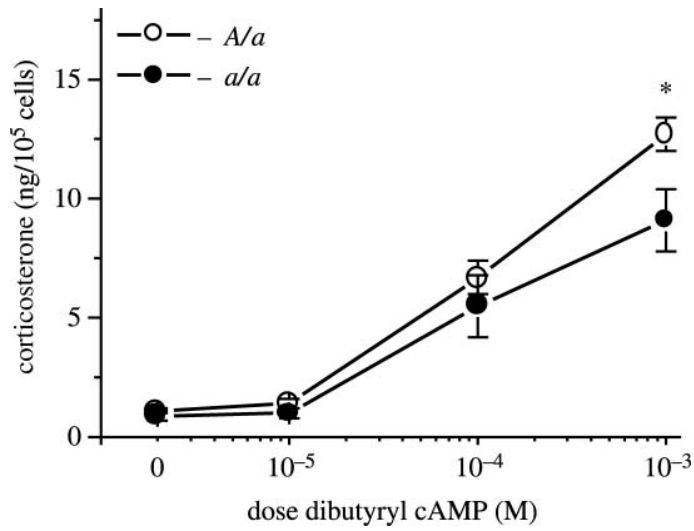

Figure 3 Effects of dibutyryl cAMP on corticosterone production in $A^{y} / a$ and a/a mice. Adrenal cells were incubated for $2 \mathrm{~h}$ in the absence or presence of various doses of dibutyryl cAMP. Each symbol represents the mean corticosterone value from two experiments. In each experiment, corticosterone production was measured in three aliquots of cell suspension obtained from five mice. Data are the means \pm S.E.M. ${ }^{*} P<0.05$ in $A^{y} / a$ mice vs a/a mice (ANOVA, post hoc comparison by NewmanKeuls test).

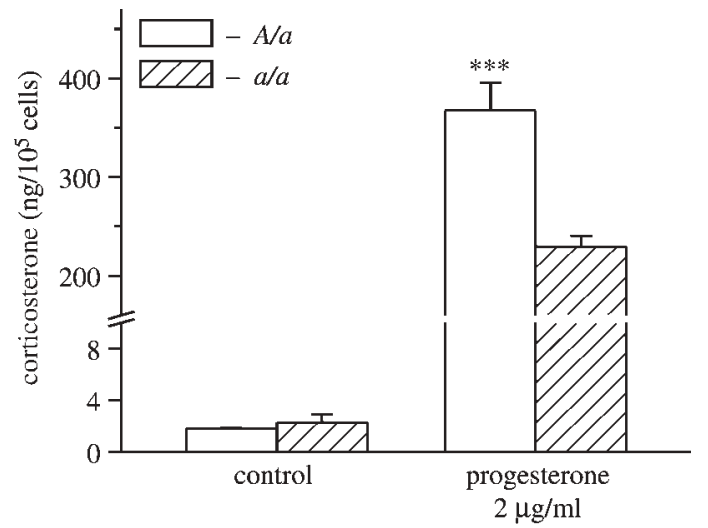

Figure 4 Effects of progesterone on corticosterone production in $A^{y / a}$ and $a / a$ mice. Adrenal cells were incubated for $2 \mathrm{~h}$ in the absence or presence of progesterone. Each column represents the mean corticosterone value from two experiments. In each experiment, corticosterone production was measured in three aliquots of cell suspension obtained from five mice. Data are the means \pm S.E.M. ${ }^{* \star *} P<0.001$ in $A^{y / a}$ mice vs a/a mice (ANOVA, post hoc comparison by Newman-Keuls test).

\section{Discussion}

We have demonstrated that ACTH-stimulated corticosterone production in adrenal cells was higher in mice with ectopic AP overexpression. This result is consistent with others who have reported that ACTHinduced corticosterone release was increased in vivo $(11,13)$ and in vitro in mice with ectopic AP overexpression (13). Agouti proteins (AP and AgRP) were shown to be antagonists of MCRs $(6,7)$. Since AP inhibits hormone action on MCRs, chronic antagonism of AP in $A^{y} / a$ mice may result in the development of some compensatory mechanisms which intensify ACTH-induced corticosterone production. The mechanisms of the enhanced activation of ACTH-induced steroidogenesis in the adrenals of $A^{y / a}$ mice are unknown. Harris et al. (11) suggested that in mice with AP overproduction, chronic, partial antagonism of MC2-R led to an increased level of expression of the ACTH receptors in the adrenal cortex. Here we suggested and tested another possible mechanism which involves post-ACTH receptor regulation of membrane $\mathrm{AC}$ and/or intracellular steroidogenic enzymes.

We used forskolin to estimate AC activity. Forskolin stimulated steroidogenesis in a dose-dependent manner except for the highest dose of $10^{-4} \mathrm{M}$. This dose of forskolin increased cAMP accumulation but decreased corticosterone production. Apparently, the reduction in corticosterone secretion at this dose of forskolin is independent of AC activation. Forskolin at a dose of $10^{-4} \mathrm{M}$, unlike lower doses, has a direct $\mathrm{Ca}^{2+}$ channel-blocking action (18), inhibits glucose transport $(19,20)$ and can decrease steroidogenic response by this means.

Contrary to ACTH, forskolin acts directly on the AC and increases cAMP level without interaction with 
any of cell-surface receptors. We did not show an influence of ectopic AP overexpression on AC activity. Although forskolin-induced cAMP accumulation was the same in $A^{y} / a$ and $a / a$ mice, the steroidogenic response was greater in $A^{y} / a$ mice compared with $a / a$ mice. This may be a consequence of the response of high intracellular steroidogenic enzymes to cAMP. Our experiments with exogenous cAMP stimulation confirmed this assumption. The capacity of AP to upregulate intracellular enzymes has been demonstrated with key intracellular lipid-metabolizing enzymes (21). The experiment with the administration of an excess of progesterone (cAMP-independent activation of steroidogenesis) indicated a higher activity of intracellular steroidogenic enzymes in $A^{y / a}$ mice. The increased enzyme activity may account for the increased sensitivity of intracellular steroidogenic enzymes to cAMP action in $A^{y} / a$ mice. A possible explanation for the rise in enzyme activity may be increased enzyme expression levels in mice with AP overexpression. The action of AP on gene expression has been shown in adipose tissue and $\beta$-cells of the pancreas gland $(16,17)$.

AP may act via a modulation of $\mathrm{Ca}^{2+}$ concentrations. Calcium plays an important role in the regulation of gene expression and enzyme activity in adrenals (22). AP was shown to increase the intracellular concentration of $\mathrm{Ca}^{2+}$ in myocytes and adipocytes $(14,15)$. It may be assumed that AP also increases intracellular concentrations of $\mathrm{Ca}^{2+}$ in the adrenal gland, stimulating steroidogenic enzyme activity.

ACTH-induced cAMP accumulation was also the same in both $A^{y} / a$ and $a / a$ adrenal cells. These data indicated that higher steroidogenesis in stimulated adrenal cells from the mice with ectopic AP overexpression did not result from changes in AC activity. Moreover, there were no correlations between corticosterone secretion and cAMP production in ACTH-induced adrenal cells. We used a physiological dose range for adrenal cell stimulation. Previously we have found (authors' unpublished data) that plasma ACTH concentrations in both $A^{y} / a$ and $a / a$ mice varied from $2 \times 10^{-13} \mathrm{M}$ (basal) to $2 \times 10^{-10} \mathrm{M}$ (stress induced). ACTH at $10^{-13}$ and $10^{-12} \mathrm{M}$ stimulated steroidogenesis without an increase in cellular cAMP synthesis. Upon the addition of higher concentrations of ACTH $\left(10^{-11}\right.$ and $\left.10^{-10} \mathrm{M}\right)$, cellular cAMP synthesis was significantly increased, but did not lead to a further increase of corticosterone secretion. This phenomenon has also been demonstrated by other authors (23-25). The lack of correlation between corticosterone secretion and cAMP production at the lower ACTH dosage may be due to the binding of cAMP with the cAMP-dependent protein kinase regulatory subunit, which does not allow measurement of the actual increase of cAMP production in cells (26).

On the other hand, ACTH at the lower concentrations may not stimulate steroidogenesis via AC. It has been demonstrated that low ACTH concentrations stimulate steroidogenesis in adrenal cells, increasing $\mathrm{Ca}^{2+}$ influx via T-type $\mathrm{Ca}^{2+}$ channels $(27,28)$. The 15-lipoxygenase metabolite(s) of arachidonic acid is also a second messenger for ACTH (25). Higher steroidogenesis in $A^{y} / a$ mice may be due to a higher response by the adrenal cells to the second messengers other than cAMP. Thus AP may influence AC-dependent and AC-independent ACTH signaling pathways and so affect steroidogenesis.

AP normally is not expressed in adrenals in contrast to AgRP (29). Adrenal AgRP was shown to have an inhibitory paracrine effect on stimulated steroidogenesis acting via MC3-R and MC4-R $(4,5,12)$. The pleiotropic effect of $A^{y}$ mutation on energy balance is considered to be due to AP inhibitory action at MC3$\mathrm{R}$ and MC4-R in the hypothalamus (29). If this was the case for the adrenal, overexpression of AP would inhibit adrenal steroidogenesis. We found a contrary effect. Possibly adrenal AP exerts two opposite effects in $A^{y} / a$ mice: it inhibits steroidogenesis by blocking MC3-R and MC4-R for $\alpha \mathrm{MSH}$ action and stimulates steroidogenesis by increasing steroidogenic enzyme activity. The absence of differences between the adrenal function of $A^{y} / a$ and $a / a$ mice under resting conditions may be due to interference by the opposing tendencies of AP action. The prevalence of one or other effect may depend on the type of adrenal stimulation.

We have here demonstrated, for the first time, that ectopic AP overexpression increased stimulated corticosterone production and intracellular steroidogenic enzyme activity without an effect on AC activity. The exact mechanisms that enhance ACTH-induced steroidogenesis in $A^{y} / a$ mice remain to be investigated. Understanding the role of APs in the regulation of steroidogenesis in rodents can help to elucidate the physiological function of APs in human tissues.

\section{Acknowledgements}

This work was supported by research grants from the Russian Fund of Basic Researches No. 01-04-488868 and The State Program Supporting Leading Scientific Schools in Russia No. 1515.2003.4.

\section{References}

1 Ollmann MM, Wilson BD, Yang YK, Kerns JA, Chen Y, Gantz I \& Barsh GS. Antagonism of central melanocortin receptors in vitro and in vivo by agouti-related protein. Science $1997 \mathbf{2 7 8} 135-138$.

2 Bultman SJ, Michaud EJ \& Woychik RP. Molecular characterization of the mouse agouti locus. Cell 199271 1195-1204.

3 Wilson BD, Ollmann MM, Kang L, Stoffel M, Bell GI \& Barsh GS. Structure and function of ASP, the human homolog of the mouse agouti gene. Human Molecular Genetics 19954 223-230.

4 Bicknell AB, Lomthaisong K, Gladwell RT \& Lowry PJ. Agouti related protein in the rat adrenal cortex: implications for novel autocrine mechanisms modulating the actions of pro-opiomelanocortin peptides. Journal of Neuroendocrinology $2000 \quad 12$ 977-982. 
5 Dhillo WS, Small CJ, Gardiner JV, Bewick GA, Whiteworth EJ, Jethwa PH, Seal LJ, Ghatei MA, Hinson JP \& Bloom SR. Agoutirelated protein has an inhibitory paracrine role in the rat adrenal. Biochemical and Biophysical Research Communications 2003301 102-107.

6 Lu DS, Willard D, Patel IR, Kadwell S, Overton L, Kost T, Luther M, Chen W, Woychik RP, Wilkison WO et al. Agouti protein is an antagonist of the melanocyte-stimulating-hormone receptor. Nature $1994371799-802$

7 Yang YK, Ollmann MM, Wilson CD, Yamada T, Barsh GS \& Gantz I. Effects of recombinant Agouti-signaling protein on melanocortin action. Molecular Endocrinology 199711 274-280.

8 Ollmann MM, Lamoreux ML, Wilson BD \& Barsh GS. Interaction of agouti protein with the melanocortin 1 receptor in vitro and in vivo. Genes and Development 199812 316-330.

9 Siegrist W, Drozdz R, Cotti R, Willard WO, Wilkison WO \& Eberle AN. Interactions of a-melanotropin and agouti on B16 melanoma cells: evidence for inverse agonism of agouti. Journal of Receptor and Signal Transduction Research 199717 75-98.

10 De Souza J, Butler AA \& Cone RD. Disproportionate inhibition of feeding in $A^{y}$ mice by certain stressors: a cautionary note. Journal of Neuroendocrinology $2000 \mathbf{7 2}$ 126-132.

11 Harris R, Zhou J, Shi M, Redmann S, Mynatt R \& Ryan DH. Overexpression of agouti protein and stress responsiveness in mice. Physiology and Behavior 200173 599-608.

12 Doghman M, Delagrange P, Blondet A, Berthelon MC, Durand P, Naville D \& Begeot M. Agouti-related protein antagonizes glucocorticoid production induced through melanocortin 4 receptor activation in bovine adrenal cells: a possible autocrine control. Endocrinology 2004145 541-547.

13 Karkaeva NR, Bahzan NM, Yakovleva TV \& Makarova EM. Function of the hypothalamo-pituitary-adrenal system in mice with ectopic overexpression of agouti protein. Russian Physiological Journal $2003 \mathbf{8 9} 851-857$.

14 Kim JH, Kiefer LL, Woychik RP, Wilkison WO, Truesdale A, Ittoop O, Willard D, Nichols J \& Zemel MB. Agouti regulation of intracellular calcium. Role of melanocortin receptor. American Journal of Physiology 1997272 379-384.

15 Zemel MB. Agouti/melanocortin interactions with leptin pathways in obesity. Nutrition Reviews $199856271-274$.

16 Claycombe KJ, Xue BZ, Mynatt RL, Zemel MB \& Moustaid-Moussa N. Regulation of leptin by agouti. Physiological Genomics 20002 $101-105$.

17 Zemel MB, Kim JH, Woychik RP, Michaud EJ, Kadwell SH, Patel IR \& Wilkison WO. Agouti regulation of intra cellular calcium: role in the insulin resistance of viable yellow mice. PNAS 199592 $4733-4737$.
18 Kuryshev YA, Childs GV \& Ritchie AK. Corticotropin-releasing hormone stimulation of $\mathrm{Ca}^{2+}$ entry in corticotropes is partially dependent on protein kinase A. Endocrinology $19951363925-3935$.

19 Laurenza A. Sutkowski EM \& Seamon KB. Forskolin: a specific stimulator of adenylyl cyclase or a diterpene with multiple sites of action? Trends in Pharmacological Sciences $198910442-447$.

20 Martin GE, Seamon KB, Brown FM, Shanahan MF, Roberts PE \& Henderson PJ. Forskolin specifically inhibits the bacterial galactose- $\mathrm{H}+$ transport protein, GalP. Journal of Biological Chemistry $199426924870-24877$.

21 Jones BH, Kim JH, Zemel MB, Woychik RP, Michaud EJ, Wilkison WO \& Moustaid N. Upregulation of adipocyte metabolism by agouti protein: possible paracrine actions in yellow mouse obesity. American Journal of Physiology $1996270192-196$.

22 Gallo-Payet N, Grazzini E, Cote M, Chouinard L, Chorvatova A, Bilodeau L, Payet MD \& Guillon G. Role of $\mathrm{Ca}^{2+}$ in the action of adrenocorticotropin in cultured human adrenal glomerulosa cells. Journal of Clinical Investigation 199698 460-466.

23 Mertz LM \& Pedersen RC. The kinetics of steroidogenesis activator polypeptide in the rat adrenal cortex. Journal of Biological Chemistry $1989 \mathbf{2 6 4} 15274-15279$.

24 Schimmer BP. Cyclic nucleotides in hormonal regulation of adrenocortical function. Advances in Cyclic Nucleotide Research 1980 $13181-214$.

25 Yamazaki T, Kimoto T, Higuchi K, Ohta Y, Kawato S \& Kominami S. Calcium ion as a second messenger for o-nitrophenylsulfenyl-adrenocorticotropin (NPS-ACTH) and ACTH in bovine adrenal steroidogenesis. Endocrinology $1998 \quad 139$ $4765-4771$.

26 Tepperman J \& Tepperman HM. ACTH and adrenal glucocorticoids. In Metabolic and Endocrine Physiology: An Introductory Text, pp 313-370. Ed. YI Azhip. London: Year Book Medical Publishers, Inc., 1987.

27 Kimoto T, Ohta Y \& Kawato S. Adrenocorticotropin induces calcium oscillations in adrenal fasciculata cells: single cell imaging. Biochemical and Biophysical Research Communications 1996221 25-30.

28 Mlinar B, Biagi BA \& Enyeart JJ. A novel $\mathrm{K}^{+}$current inhibited by adrenocorticotropic hormone and angiotensin I1 in adrenal cortical cells. Journal of Biological Chemistry $19932 \mathbf{2 6 8} 8640-8644$.

29 Dinulescu DM \& Cone RD. Agouti and Agouti-related protein: analogies and contrasts. Journal of Biological Chemistry 2000 $2756695-6698$

Received 11 March 2004

Accepted 21 July 2004 